Research Article

\title{
Innovation Efficiency of High-Tech SMEs Listed in China: Its Measurement and Antecedents
}

\author{
Lixia Liu $\mathbb{D}^{1},{ }^{1}$ Yaming Hou, ${ }^{2}$ Xueli Zhan, ${ }^{2,3}$ and Zongxian Wang $\mathbb{D}^{2}$ \\ ${ }^{1}$ School of Economics, Tianjin University of Commerce, Tianjin, China \\ ${ }^{2}$ College of Management and Economics, Tianjin University, Tianjin, China \\ ${ }^{3}$ School of Economics, Beijing Wuzi University, Beijing 101149, China \\ Correspondence should be addressed to Lixia Liu; liulixia77@163.com and Zongxian Wang; zongxianw201709@126.com
}

Received 26 September 2020; Revised 18 November 2020; Accepted 3 December 2020; Published 16 December 2020

Academic Editor: Lijun Pei

Copyright $\odot 2020$ Lixia Liu et al. This is an open access article distributed under the Creative Commons Attribution License, which permits unrestricted use, distribution, and reproduction in any medium, provided the original work is properly cited.

\begin{abstract}
Innovation efficiency is an important index to measure the innovation performance of high-tech enterprises. Numerous researches have been conducted on innovation efficiency at national, regional, and sectoral levels, while there are comparatively few studies on the innovation efficiency of high-tech small- and medium-sized enterprises (SMEs) from a micro perspective. Therefore, innovation efficiency of 251 high-tech SMEs listed in China from 2012 to 2015 is measured with the super-SBM model in this paper. The results suggest that the overall innovation efficiency is low but shows an upward trend. In addition, the antecedents of innovation efficiency are explored using the panel regression model and the conclusions are as follows: (1) government subsidies, ownership concentration, and market competition deter enterprise innovation efficiency, and the impact of ownership concentration is found to be the most significant; (2) firm size and asset-liability ratio bear positively on enterprise innovation efficiency, with the effect of asset-liability ratio being greater; (3) firm age has significantly positive effects on scale efficiency but not on innovation efficiency and pure technical efficiency.
\end{abstract}

\section{Introduction}

The Organization for Economic Co-operation and Development (OECD) views technological innovation as comprising new products or services and the making of significant changes in the products and processes, and innovation is realized when the new product or service is introduced in the market [1]. Technology innovation is the driving force in promoting economic growth [2-5], particularly so for developing economies. In the case of China, the $18^{\text {th }}$ Party Congress of China put forward the implementation of innovation driven development strategy and stressed that technology innovation is the strategic support for improving social productivity and overall national strength and must be put at the heart of the overall national development. For China, it is a particularly urgent thing as china is at a crucial stage of economic transformation and development. China is at a crucial stage of economic transformation and development. Technological innovation is an inevitable component of promoting the economic leap forward in the development and industrial restructuring in China. As a critical part of the technological innovation ecosystem, high-tech enterprise is a key cog of China's national innovation system [6]. Such enterprises play a significant role in gathering the needed scientific and technological resources, promoting scientific and technological research, transforming the achievements, and ultimately directly or indirectly contributing to the needed economic transformation [7].

At the same time, more than $70 \%$ of these high-tech enterprises are small- and medium-sized enterprises (SMEs). Therefore, the development of high-tech SMEs is related to the innovation ability of the whole country. Nevertheless, high-tech SMEs are facing many problems, such as high operating cost, lack of talent, and difficult in financing, which can significantly restrict the innovation capacity of the high-tech SMEs in the long run [8-11]. Enhancing of high-tech SMEs' innovation capability should 
not only put emphasis on innovation output but also focus on the input-output efficiency of innovation [12]. Therefore, it is meaningful to objectively evaluate the innovation efficiency of high-tech SMEs and explore the factors that affect innovation efficiency.

This paper contributes to this stream of research. We calculate the innovation efficiency of high-tech SMEs listed in China's Growth Enterprises Market (GEM), a market of the Shenzhen stock exchange. China's GEM is a significant case study for our purposes: it is a Chinese NASDAQ-style market that provides financing for high-growth and highinnovation SMEs and lists more than 700 companies, $90 \%$ of which are high-tech enterprises.

In this paper, we contribute to the existing literature on high-tech enterprises' innovation efficiency in three respects. First, we focus purely on SMEs and hope this research can help to improve the overall level of high-tech SMEs' innovation efficiency. Numerous researches have been focused on the innovation efficiency of nations, regions, industries, and large enterprises. So far, there are relatively few studies on the innovation efficiency of hightech SMEs. Second, we shed more light on the effects of internal and external factors on high-tech SMEs' innovation efficiency. This issue is largely overlooked in the research literature that instead mostly examines the effects on innovation inputs and innovation outputs. We not only analyze the impact of the factors on the comprehensive innovation efficiency of high-tech SMEs but also examine the impact on the pure technical efficiency and scale efficiency. Our third contribution is methodological. Although the super-SBM model has proven to be an effective analytical tool for studying efficiency, there are few researches on innovation efficiency. Based on the super-SBM model, we obtain more real and objective values of innovation efficiency. This paper uses the super-SBM model to analyze high-tech SMEs listed in China, which not only provided examples of the application of the super-SBM model in the research field of innovation efficiency but also has practical significance for empirical analysis on the innovation efficiency of China's high-tech SMEs.

The remainder of the paper is organized as follows: section 2 provides a brief view of the extant literature. Section 3 establishes the super-SBM model and panel regression model and introduces the data source. Section 4 provides the empirical results and discussion, which include the evaluation of high-tech SMEs' innovation efficiency and study of its antecedents. Section 5 presents the conclusion and some policy suggestions.

\section{Literature Review}

Innovation efficiency is the relative capability of an enterprise to maximize innovation outputs given a certain quantity of innovation inputs [12]. It is a key index to measure the ability of technological innovation and has attracted much research attention in recent years [12]. From the literature, we note that the study of innovation efficiency from four perspectives including enterprises [13-15], industries [16-18], regions [19-21], and nations [22, 23].
High-tech enterprises focus primarily on the development of new products and new production processes [24-26]. It has the characteristics of high investment, high innovation, and high returns [27]. In recent years, innovation efficiency of high-tech enterprises has gradually attracted people's attention. The studies of high-tech enterprises' innovation efficiency are mainly implemented from two aspects: the determination and analyzing the antecedents of innovation efficiency. In general, there are two approaches to calculate high-tech enterprises' innovation efficiency, namely, the nonparametric method and parametric method. The stochastic frontier analysis (SFA) method proposed by Aigner, Lovell, and Schmidt is a parametric method to analyze the high-tech enterprises' innovation efficiency [28-30]. Data envelopment analysis (DEA) first proposed by Charnes, Cooper, and Rhodes (1978), is a nonparametric method to evaluate efficiency $[31,32]$. Compared with the SFA method, the DEA method does not need to estimate the production function and avoid the problems caused by the improper function form. The DEA method also can be used to evaluate the efficiency of DMUs with multi-input and multi-output. So, the DEA method is widely applied to the measures of innovation efficiency. Using the DEA method, Yi, Peng, and Yu calculated the high-tech industry innovation efficiency in China's 27 provinces between 2000 and 2014 [33]. Li et al. evaluated the efficiency of regional high-tech industries in China from 1998 to 2011 based on the metafrontier dynamic DEA method [34].

Prior studies have also investigated the technological innovation efficiency by identifying the effect of property rights [35], managerial ownership [36], government subsidies [37], regional agglomeration [38], and industrial development environment [39]. Jefferson et al. studied the impact of ownership on innovation efficiency and proposed that the innovation efficiency of foreign owned enterprises exceeds that of the local enterprises [35]. Zhu and Zhou noted that equity balance had a positive influence on the high-tech enterprise innovation efficiency, but there was a significant nonlinear relationship between managerial ownership and enterprise innovation efficiency [36]. Hong et al. explored the influence of government incentives on innovation performance of the high-tech industries and found that government grants exerted a negative influence on innovation efficiency [37]. Jiao et al. summarized an inverse U-shaped relationship between the high-tech industry regional agglomeration level and R\&D efficiency [38]. Liu et al, found that the shortage of R\&D staff and insufficient $R \& D$ expenditure are the main reasons for the low R\&D investment efficiency [39].

The literature so far analyzes the determination and antecedents of technological innovation efficiency at the national, regional, and sectoral levels. Very few studies have been endeavored to evaluate the innovation efficiency of high-tech enterprises, and most of them have used macrodata or specific industry data. Further, while there is an abundance of the literature on large Chinese enterprises' innovation efficiency, the work on SMEs is scant. This just provides us with research opportunities. To quantify the 
innovation efficiency of China's SMEs, we use the superSBM model on the Chinese Growth Enterprise Market (GEM) listed firm data, and then employ panel regression to analyze the relevant factors that affect innovation efficiency.

\section{Method}

3.1. Super-SBM Model. Data envelopment analysis (DEA) first proposed by Charnes, Cooper, and Rhodes, is a popular nonparametric method for evaluating the relative effectiveness of the decision-making units (DMUs) on the basis of multiple inputs and outputs [31]. Even though the classical DEA model has been widely applied in many areas, it still suffers from several inherent limitations. To deal with the problems, many DEA improved models are proposed in recent years. Peterson and Anderson developed a superefficiency model, which could rank efficient DMUs [40]. In this approach, the super-efficiency value of an efficient DMU may be larger than one. Tone (2001) introduced a slacksbased measure (SBM) model, which directly deals with input and output slacks in traditional DEA [41]. On the basis of the SBM model, Tone presented a super-SBM model of efficiency to rank efficient DMUs [42]. Compared to the traditional DEA model, the super-SBM model can not only eliminate the radial and oriented deviation but also provide more reasonable efficiency values for subsequent multiple regression analysis. This paper applies the super-SBM model to evaluate the innovation efficiency of high-tech SMEs.

If suppose there exist $n$ DMUs, then each DMU has $m$ inputs and $s$ outputs. $X=\left(x_{i j}\right)^{m \times n}$ is an m-dimensional input vector of DMUs $j$, and $Y=\left(y_{i j}\right)^{s \times n}$ is a s-dimensional output vector of DMUs $j$. A certain DMU $\left(x_{0}, y_{0}\right)$ is defined as follows:

$$
\begin{aligned}
& x_{0}=X \lambda+s^{-}, \\
& y_{0}=Y \lambda-s^{+},
\end{aligned}
$$

with $\lambda \geq 0, s^{-} \geq 0$, and $s^{+} \geq 0$, where $s^{-}$and $s^{+}$are the slack variable of the input and the slack variable of the output, respectively; and $\lambda$ is the weight of DMU $\left(x_{0}, y_{0}\right)$.

Based on the SBM model, the efficiency score of DMUs are evaluated as follows:

$$
\begin{gathered}
\min \rho=\frac{1-1 / m \sum_{i=1}^{m} s_{i}^{-} / x_{i 0}}{1-1 / s \sum_{r=1}^{s} s_{r}^{+} / y_{r 0}}, \\
\text { s.t. }\left\{\begin{array}{l}
x_{0}=X \lambda+s^{-}, \\
y_{0}=Y \lambda-s^{+}, \\
s^{-} \geq 0, s^{+} \geq 0, \lambda \geq 0 .
\end{array}\right.
\end{gathered}
$$

The above program can be transformed into a linear program using the method of Charnes et al. [31]. Suppose $\left(\rho^{*}, \lambda^{*}, s^{-*}, s^{+*}\right)$ is an optimal solution for the SBM model. When $\rho^{*}=1$, i.e., $s^{+*}=0$ and $s^{-*}=0$, the DMU $\left(x_{0}, y_{0}\right)$ is SBM-efficient in the presence of undesirable outputs.

After measuring the efficiency values with the SBM model, the super-efficiency issues under the assumption that the DMU $\left(x_{0}, y_{0}\right)$ is SBM-efficient are discussed. The super- efficiency of DMU $\left(x_{0}, y_{0}\right)$ as the optimal objective function value $\delta_{0}^{*}$ is defined as follows:

$$
\min \delta_{0}=\frac{1 / m \sum_{i=1}^{m} \widehat{x}_{i} / x_{i 0}}{1 / s \sum_{r=1}^{s} \widehat{y}_{r} / y_{r 0}}
$$

s.t. $\left\{\bar{x} \geq \sum_{j=1, j \neq 0}^{n} x_{j} \lambda_{j}, \bar{y} \leq \sum_{j=1, j \neq 0}^{n} y_{j} \lambda_{j}, \bar{x} \geq x_{0}, 0 \leq \bar{y} \leq y_{0} . \lambda_{j} \geq 0\right.$,

where $\bar{x}$ and $\bar{y}$ are decision variables with respect to inputs and outputs, respectively. The above super-SBM program can also be transformed into a linear program using the method of Charnes et al. [31]. The SBM-efficient DMUs can be effectively ranked in the super-SBM model. The superSBM model provides a more accurate efficiency evaluation. Thus, we use the super-SBM model to evaluate the innovation efficiency of high-tech SMEs in this study.

3.2. Panel Regression Model. Panel regression model is used to analyze the influence of the antecedents on innovation efficiency. The panel regression model is written as follows:

$$
y_{i t}=\beta_{0}+\beta_{i t} x_{i t}+\varepsilon_{i t}
$$

where $i=1,2, \cdots, N$ is the individual dimension and $t=$ $1,2, \cdots, T$ is the time dimension; $y_{i t}$ is the interpreted variable vector; $x_{i t}$ is the explanatory variable vector; $\beta_{i t}$ is the parameter vector; and $\varepsilon_{i t} \sim N\left(0, \sigma^{2}\right)$ is a random perturbation.

\subsection{Selection of Variables and Data Source}

3.3.1. Efficiency Evaluation Variables. We select R\&D personnel, R\&D expenditure, and fixed assets as the input indicators and select the main business income and patent application as the output indicators. Table 1 summarizes the input and output variables. The descriptions of the variables are listed as follows:

(1) $R \& D$ personnel. $R \& D$ personnel refer to all staff in either fundamental research, application research, or experimental development. Because the information disclosure system of the listed companies in China does not require the listed company to disclose the data on the R\&D personnel, this paper selects the technical personnel as a proxy input indicator of the labor force.

(2) $R \& D$ expenditure. The amount of money spent on innovation activities is also a key input indicator to measure innovation efficiency. Based on previous research, we chose the enterprise's annual R\&D expenditure as the capital input indicator [37].

(3) Fixed assets. The quantity and quality of fixed assets not only reflect the enterprise's scale and economic strength but also impact the ability of enterprise's innovation. Therefore, the enterprise's annual total 
TABLE 1: Brief description of input and output variables.

\begin{tabular}{lcc}
\hline Index & Variable & Interpretation of indicators \\
\hline \multirow{2}{*}{ Input index } & R\&D personnel & The number of technical personnel of enterprise per year \\
& R\&D expenditure & Fixed assets \\
Output index & Patent application & The enterprise's annual total expenditure on R\&D activities \\
& Main business income & The enterprise's annual total fixed assets \\
\end{tabular}

fixed assets are also used as an input index to evaluate innovation efficiency.

(4) Patent application. Since the number of patents granted is affected by patent institutions, the number of patent applications can better reflect the authenticity of innovation output than the number of patents granted [43]. Therefore, this paper uses the number of patent applications to measure the patent output.

(5) Main business income. The indirect outcome of the enterprise's innovation activities should be to reduce the cost of production, increase the market share of the products, and increase sales income. The sales revenue of the new products has been widely used. However, the annual report information disclosure system of Chinese listed companies does not require listed companies to disclose the sales revenue of new products. Therefore, we use the main business income as the next best proxy.

3.3.2. Selection of Antecedents. The panel regression model is proposed in equation (3). The dependent variables are innovation efficiency (IE), pure technical efficiency (PTE), and scale efficiency (SE). Including both the internal and external antecedents, government subsidies, ownership concentration, firm size, asset-liability ratio, market competition, and firm age are selected as the independent variables to explore the main factors affecting the high-tech SMEs' innovation efficiency. Table 2 gives the brief description of all variables.

Government subsidies (GS). It is a form of financial support to the enterprise generally with the aim of promoting technological innovation. The relationship between government subsidy and innovation efficiency is contentious. It is generally believed that the higher the government subsidies are, the higher the enterprise innovation investment is, and the higher the enterprise innovation performance is [44-46]. However, Hong et al. [37], Guan and Chen [19] argued that government subsidies had a substitution effect on the enterprise's R\&D investment. The enterprise's annual R\&D expenditures from the government are used to represent the government subsidies.

Ownership concentration (OC). It is the main indicator to measure the ownership structure of enterprises. It can improve the supervision ability of large shareholders, prompt top managers to pay attention to the enterprise's technological innovation and long-term development, and reduce short-sighted decision-making [47]. The increase in ownership concentration is conducive to the improvement of enterprise's innovation efficiency. But Chen et al. argued that when an enterprise's ownership becomes too concentrated, large shareholders will become more cautious and risk averse and invest less in innovation projects [48]. The shareholding ratio of the top ten major shareholders is chosen as the index for ownership concentration in this paper.

Firm size (Size). It is commonly held that large firms benefit from economies of the scale and have greater technical knowledge and management experience to improve their response time to a new technique. Empirical studies also support the idea that large enterprises have more advantages in innovation activities, and $\mathrm{R} \& \mathrm{D}$ performance is higher than small enterprises [49]. Wang and Tsai found there was no difference between large enterprises and SMEs [50]. At present, there is no consistent conclusion regarding the impact of firm size on innovation efficiency. Some scholars believe that firm size has a positive effect on innovation efficiency [51]. Some scholars argue that the cost of maintaining existing market benefits and the increasing cost of organizational change for large companies will inhibit the enterprise's innovation efficiency, and small enterprises have more advantages in terms of organizational flexibility and market sensitivity and are easier to achieve breakthroughs in innovation. Therefore, innovation efficiency does not change positively with firm size [52]. Due to many factors such as market position and industrial upgrading, many other scholars hold the opinion that there is a complex nonlinear relationship between firm size and innovation efficiency [53]. The proxy of firm size is measured by the enterprise's total assets in this paper.

Asset-liability ratio (ALR). It indicates the proportion of an enterprise's assets that is being financed by borrowed money. The relationship between assets-liability ratio and innovation efficiency is also a contentious issue. High assetliability ratio means heavy debt repayment pressure, which will hinder the normal operation and inhibit the enterprises' technological innovation. However, high asset-liability ratio can also be transformed into a driving force to promote the innovation efficiency of enterprises. The enterprise's total debt to total assets ratio represents asset-liability ratio in this paper.

Market competition (MC). The ratio of selling expenses to operating income is chosen as the index for market competition in this paper. The larger the ratio of selling expenses to operating income, the higher the sales cost of the unit's operating income in the market, and the greater the competition in the industry. The enhancement of market 
TABLE 2: Brief description of influential factors.

\begin{tabular}{lcc}
\hline Variable & Label & Interpretation of indicators \\
\hline Innovation efficiency & IE & The innovation efficiency value is calculated by the super-SBM model \\
Government subsidies & GS & The enterprise's annual R\&D expenditures from the government \\
Ownership concentration & OC & The proportion of the top ten largest shareholders \\
Firm size & Size & The enterprise's annual total assets \\
Asset-liability ratio & ALR & The ratio of total debt to total assets \\
Market competition & MC & Tge
\end{tabular}

competition pressure is beneficial to promoting enterprise innovation [54]. Nevertheless, excessive competition can decline corporate profits and inhibit innovation.

Firm Age (Age). Empirical studies have found both negative and positive effects of firm age on innovation. Majumdar and Balasubramanian and Lee suggested that older enterprises are liable to experience some form of inertia, which may hinder innovation $[55,56]$. However, Herriott et al. suggested that the older enterprise has much more reputation, managerial knowledge, and market position [57]. So, firm age has a positive effect on new product development and innovative outcomes [58]. Firm age is defined as the number of years of incorporation of the enterprise in this paper.

To satisfy the requirement of stationarity, all the explanatory variables are logarithmically transformed. The factors are standardized by taking natural logarithms.

$$
\begin{aligned}
\mathrm{IE}_{i t}= & \beta_{0}+\beta_{1} \ln \left(\mathrm{GS}_{i t}\right)+\beta_{2} \ln \left(\mathrm{OC}_{i t}\right)+\beta_{3} \ln \left(\mathrm{Size}_{i t}\right) \\
& +\beta_{4} \ln \left(\mathrm{ALR}_{i t}\right)+\beta_{5} \ln \left(\mathrm{MC}_{i t}\right)+\beta_{6} \ln \left(\mathrm{Age}_{i t}\right)+\varepsilon_{i t},
\end{aligned}
$$

where $I E_{i t}$ denotes the high-tech SMEs' innovation efficiency value of enterprise $i$ in year $t . \beta_{0}, \beta_{1}, \beta_{2}, \cdots, \beta_{6}$ represent the unknown parameters and $\varepsilon_{i t}$ is the random error term.

3.3.3. Data Source. This paper selects the high-tech SMEs with at least 4 years of continuous disclosure of government subsidies data from 2012 to 2015 . In the process of the data selection, we eliminated those enterprises with outliers and missing values in selected variables to obtain the final selection of 251 enterprises as our sample. The data are mostly from the wind information database and Tai'an database.

\section{Results and Discussion}

4.1. Determination of High-Tech SMEs' Innovation Efficiency. Using the super-SBM model, we measure the high-tech innovation efficiency of 251 listed firms in the Chinese GEM from 2012 to 2015 displayed in Tables 3 and 4. Table 3 shows the increasing high-tech SMEs innovation efficiency. Innovation efficiency increases from a relatively low base of 0.3636 in 2012 to 0.4218 in 2014 . Also, due to the decline in pure technical efficiency, innovation efficiency dropped from 0.4218 in 2014 to 0.3859 in 2015.

In terms of the contribution, innovation efficiency is clearly promoted by scale efficiency but hampered by pure
TABLE 3: Innovation efficiency value of high-tech SMEs (2012-2015).

\begin{tabular}{lcccc}
\hline & 2012 & 2013 & 2014 & 2015 \\
\hline Innovation efficiency (IE) & 0.3636 & 0.4011 & 0.4218 & 0.3859 \\
Pure technical efficiency (PTE) & 0.4823 & 0.5765 & 0.5697 & 0.5079 \\
Scale efficiency (SE) & 0.7644 & 0.7134 & 0.7489 & 0.7797 \\
\hline
\end{tabular}

TABle 4: Efficiency distribution of high-tech SMEs (2012-2015).

\begin{tabular}{lcccc}
\hline Efficiency distribution & 2012 & 2013 & 2014 & 2015 \\
\hline $1-5.0$ & 9 & 8 & 14 & 18 \\
$0.8-0.999$ & 0 & 8 & 7 & 5 \\
$0.6-0.799$ & 9 & 18 & 18 & 15 \\
$0.4-0.599$ & 47 & 61 & 59 & 35 \\
$0.2-0.399$ & 134 & 123 & 123 & 134 \\
$0.0-0.199$ & 52 & 33 & 30 & 47 \\
\hline
\end{tabular}

technical efficiency. In the period 2012-2015, the value of scale efficiency was high and continued to increase, as shown in Table 3. This indicates that the scale of the high-tech SMEs' technological innovation has been increasing. The value of pure technical efficiency was middling around 0.5341 , which suggests that the low level of the pure technical efficiency is the main reason of the low level of high-tech SMEs' technological innovation efficiency.

From the distribution of the innovation efficiency values in Table 4, for the period 2012-2015, the number of technical efficient enterprises is $9,8,14$, and 18 , respectively. The proportion of enterprises with synthetic technical efficiency value exceeding 0.6 is $7.17 \%, 13.55 \%, 15.54 \%$, and $14.96 \%$, respectively, suggesting that more than $80 \%$ of the high-tech SMEs have a very low level of innovation efficiency.

4.2. Analysis of Antecedents on High-Tech SMEs' Innovation Efficiency. Using the panel regression model and the software of Stata ver.14.0, we analyzed the influence of these factors on the high-tech SMEs' innovation efficiency. The results are shown in Table 5.

The results as stated in Table 5 point to several findings:

(1) Government subsidies have a significant negative influence on the high-tech SMEs' innovation efficiency and pure technical efficiency. However it has no significant effect on the scale efficiency. A $1 \%$ increase in GS leads to a $0.0229 \%$ and $0.025 \%$ drop in the high-tech SMEs' innovation efficiency and pure technical efficiency, respectively. This result is 
TABLE 5: Panel regression results.

\begin{tabular}{lccc}
\hline Explanatory variable & IE & PTE & SE \\
\hline $\ln G S$ & $-0.0229^{* * *}(0.0088)$ & $-0.025^{* * *}(0.0087)$ & $-0.0039(0.0071)$ \\
$\ln$ OC & $-0.1351^{* *}(0.0542)$ & $-0.1181^{* *}(0.0531)$ & $-0.0088(0.0438)$ \\
$\ln$ Size & $0.0205^{* * *}(0.0208)$ & $0.0151^{* *}(0.0203)$ & $0.0109^{* * *}(0.0168)$ \\
$\ln$ ALR & $0.0345^{* *}(0.0183)$ & $0.0276(0.018)$ & $0.0366^{* *}(0.0148)$ \\
$\ln S$ & $-0.0416^{* * *}(0.0109)$ & $-0.0447^{* * *}(0.0155)$ & $-0.0121(0.0129)$ \\
$\ln$ Age & $0.0189(0.0432)$ & $0.0566(0.0419)$ & $0.0882^{* *}(0.035)$ \\
$\beta_{0}$ & $0.8893^{* *}(0.5022)$ & $2.4229(0.4924)$ & $-1.3206^{* * *}(0.4063)$ \\
\hline
\end{tabular}

${ }^{*}, * *$, and ${ }^{* * *}$ means significance at $10 \%, 5 \%$, and $1 \%$ levels, respectively.

consistent with the finding of Hong et al. and Guan and Chen [19, 37] The government's continuous $\mathrm{R} \& \mathrm{D}$ investment in high-tech SMEs has not played a role in stimulating enterprise innovation but may have a substitution effect on the enterprise's own $\mathrm{R} \& \mathrm{D}$ investment, and resulting in a decline in the enterprise's innovation efficiency.

(2) Ownership concentration has a negative influence on the high-tech SMEs' innovation efficiency and pure technical efficiency. It also has no significant effect on the scale efficiency. Again, a 1\% increase in OC leads to a $0.1351 \%$ and $0.1181 \%$ decrease in innovation efficiency and pure technical efficiency of the hightech SMEs' innovation effort. From 2012 to 2015, the average ownership concentration of 251 high-tech SMEs listed in China are 68.25\%, 63.85\%, 59.97\%, and $57.13 \%$, respectively. The higher ownership concentration results in the stronger control ability of the large shareholders to the enterprise [47]. Yet, large shareholders may have less willingness to invest in technological innovation due to the higher risk of innovation and therefore making the innovation efficiency worse off.

(3) Firm size has a significant positive influence on the high-tech SMEs' innovation efficiency, pure technical efficiency, and scale efficiency. A $1 \%$ increase in size leads to a $0.0205 \%, 0.0151 \%$, and $0.0109 \%$ increase in the high-tech SMEs' innovation efficiency, pure technical efficiency, and scale efficiency, respectively. This suggests that the larger the high-tech enterprise is, the better potential economic strength, and more personnel and investment are expended on technological innovation, which in turn promotes innovation efficiency within the enterprise.

(4) The asset-liability ratio has a significant positive influence on the high-tech SMEs' innovation efficiency and scale efficiency. A $1 \%$ increase in ALR leads to a $0.0345 \%$ and $0.0366 \%$ increase in the hightech SMEs' innovation efficiency and scale efficiency, respectively. From 2012 to 2015, the average assetliability ratio of 251 high-tech SMEs listed in China are $20.67 \%, 24.84 \%, 28.93 \%$, and $31.03 \%$, respectively. Overall, the asset-liability ratio was very low but showed a growth trend. As the enterprise's assetliability ratio increases, enterprise R\&D investment also increases and ultimately leads to the improvement of enterprise's innovation efficiency. The result suggests that debt is a good driver and a great impetus to the SMEs and hence enhances the high-tech SMEs' innovation efficiency.

(5) Market competition has a significant negative influence on high-tech SMEs' innovation efficiency and pure technical efficiency. It also has no significant effect on the scale efficiency. A $1 \%$ decrease in MC leads to a $0.0416 \%$ and $0.0447 \%$ decrease in the high-tech SMEs' innovation efficiency and pure technical efficiency, respectively. The results suggest that the stiff market competition may force the hightech SMEs to innovate but not necessarily a greater focus on innovation efficiency.

(6) Firm age has a significant positive influence on hightech SMEs' scale efficiency. A $1 \%$ increase in age leads to a $0.0882 \%$ increase in the high-tech SMEs' scale efficiency. However, it has no relation to the innovation efficiency and pure technical efficiency of SMEs' technological innovation. Generally speaking, the longer an enterprise is established, the larger its scale, the stronger its capital accumulation, and the higher is its product innovation scale.

\section{Conclusion and Suggestion}

This paper describes the characteristic of China's technological innovation and suggests the necessity to improve the innovation efficiency of high-tech SMEs. Based on the sample of China's GEM listed companies from 2012 to 2015, two-stage approach is applied to evaluate high-tech SMEs' innovation efficiency in this paper. In the first stage, we calculate its comprehensive efficiency, pure technical efficiency, and scale efficiency using the super-SBM model. The results indicate that the overall level of high-tech SMEs' innovation efficiency, while low, is improving. In the second stage, we examine internal and external antecedents of innovation efficiency through the panel regression model. Based on the analysis results of the super-SBM model and panel regression model, we put forward some policy recommendations:

(1) Government subsidies, ownership concentration, and market competition have a significant negative effect on the high-tech SMEs' innovation efficiency and pure technical efficiency but have no significant effect on the scale efficiency. The negative effect of ownership concentration is perhaps the most significant. The more concentrated the ownership, the 
stronger the control of the large shareholders. Also, the enthusiasm of improving innovation efficiency is weaker. Therefore, appropriately reducing the ratio of the largest shareholders can stimulate enterprises to increase innovation investment, improve innovation performance, and innovation efficiency. In order to promote high-tech SMEs' innovation efficiency, the government also needs to take some measures. On the one hand, a fair and orderly market development environment should be established to avoid excessive competition among high-tech SMEs. The fair market competition environment helps to reduce selling expenses, improves the resource allocation efficiency, and encourages enterprises to concentrate on innovation continuously. One the other hand, the government should moderately control the government subsidies for high-tech SMEs' innovation [3]. A large amount of government innovation investment does not lead to an increase in innovation efficiency. The government should strengthen supervision of the use of subsidized funds and dynamically adjust the subsidy plan according to the innovation performance of the enterprise.

(2) Firm size and asset-liability ratio have a positive on enterprise innovation efficiency. Many innovation projects require substantial capital investment, and the amount of funds needed are increasing every year. Capital shortage is a major barrier hindering the innovation of high-tech SMEs. It is of vital importance to give full pay to the role of government subsidies' signal transmission and lead the flow of social funds and financial institutions to innovation enterprises, so that the enterprises can ease external financing constraints and increase the availability of funds. For enterprises, appropriately increasing the proportion of debt financing can reduce the enterprise's capital cost, optimize capital structure, and strengthen the management of innovation efficiency. The larger the firm size, the greater the scale effect of technological innovation. So, promoting the development and growth of enterprises and enhancing economies of scale are conducive to the improvement of high-tech SEMs' innovation efficiency. High-tech SEMs are able to expand through not only capital accumulation but also reorganization, acquisition, and merger. At the same time, a R\&D strategic alliances or an innovation hub can be formed for the SMEs enterprises to deepen R\&D capacity and promote high-tech SEMs' innovation efficiency.

(3) Firm age has significant positive effects on scale efficiency but not on innovation efficiency and pure technical efficiency. The results seem to show that firm age has a positive effect on the enterprise's experience and organizational competencies, which can help older enterprise to develop their innovation operations more efficiently. However, in younger firms, the lack of market recognition, economies of scale, and managerial knowledge means that innovation requires more effort from the organizational learning process.

As this study focused on a case study of high-tech SMEs listed in China, future study of this topic may be extended to include large enterprises. A comparative study on innovation efficiency and its antecedents among enterprises of different scales is worth exploring. In addition, empirical research on a group of developing countries is also necessary to achieve results covering other developing countries.

\section{Data Availability}

The data used to support the findings of this study are available from the corresponding author upon request.

\section{Conflicts of Interest}

The authors declare that they have no conflicts of interest regarding the publication of this paper.

\section{Acknowledgments}

This work was supported by the Tianjin Planning Leading Group Office of Philosophy and Social Sciences under (grant number TJYY17-017).

\section{References}

[1] OECD, Frascati Manual 2015: Guidelines for Collecting and Reporting Data on Research and Experimental Development", the Measurement of Scientific, Technological and Innovation Activities, Organisation for Economic Co-operation and Development, Washington, DC, USA, 2015.

[2] S. Kuznets, "Driving forces of economic growth: what can we learn from history?" Review of World Economics, vol. 116, no. 9, pp. 409-431, 1980.

[3] N. Rosenberg, Innovation and Economic Growth, OECD, Washington, DC, USA, 2004.

[4] F. Wu and J. Ma, "Evolution dynamics of agricultural internet of things technology promotion and adoption in China," Discrete Dynamics in Nature and Society, vol. 2020, Article ID 1854193, 2020.

[5] X. Zhan, Y. Tian, C. Liu, A. Hou, and J. Ma, "Study of the complexity game of supply chain green innovation introduction under EPR policy and government subsidies," Complexity, vol. 2020, Article ID 5342606, 2020.

[6] B. Bao, J. Ma, and M. Goh, "Short- and long-term repeated game behaviours of two parallel supply chains based on government subsidy in the vehicle market," International Journal of Production Research, 2020.

[7] L. Liu, Y. Zhu, and S. Guo, "The evolutionary game analysis of multiple stakeholders in the low-carbon agricultural innovation diffusion," Complexity, vol. 2020, Article ID 6309545 , 2020.

[8] R. E. Carpenter and B. C. Petersen, "Is the growth of small firms constrained by internal finance?" Review of Economics and Statistics, vol. 84, no. 2, pp. 298-309, 2002.

[9] D. Czarnitzki, "Research and development in small and medium-sized enterprises: the role of financial constraints 
and public funding," Scottish Journal of Political Economy, vol. 53, no. 3, pp. 335-357, 2006.

[10] M. S. Freel, "Are small innovators credit rationed?" Small Business Economics, vol. 28, no. 1, pp. 23-35, 2007.

[11] L. Liu, Y. Huang, and X. Zhan, "The evolution of collective strategies in SMEs' innovation: a tripartite game analysis and application," Complexity, vol. 2019, Article ID 9326489, 2020.

[12] C. Cruz-Cázares, C. Bayona-Sáez, and T. García-Marco, "You can't manage right what you can't measure well: technological innovation efficiency," Research Policy, vol. 42, no. 6-7, pp. 1239-1250, 2013.

[13] E. Revilla, J. Sarkis, and A. Modrego, "Evaluating performance of public-private research collaborations: a DEA analysis," Journal of the Operational Research Society, vol. 54, no. 2, pp. 165-174, 2003.

[14] N. O'Regan, A. Ghobadian, and D. Gallear, "In search of the drivers of high growth in manufacturing SMEs," Technovation, vol. 26, no. 1, pp. 30-41, 2006.

[15] J. C. Guan, R. C. M. Yam, C. K. Mok, and N. Ma, “A study of the relationship between competitiveness and technological innovation capability based on DEA models," European Journal of Operational Research, vol. 170, no. 3, pp. 971-986, 2006.

[16] J. Schmidt-Ehmcke and P. Zloczysti, "Industries at the world technology frontier: measuring R\&D efficiency in a nonparametric DEA framework," Centre for Economic Policy Research Discussion Paper, Article ID DP8579, 2011.

[17] C. Lee, J. H. Kim, and D. Lee, "Intra-industry innovation, spillovers, and industry evolution: evidence from the Korean ICT industry," Telematics and Informatics, vol. 34, no. 8, pp. 1503-1513, 2017.

[18] S. Lin, J. Sun, and S. Wang, "Dynamic evaluation of the technological innovation efficiency of China's industrial enterprises," Science and Public Policy, vol. 46, no. 2, pp. 232-243, 2019.

[19] J. Guan and K. Chen, "Measuring the innovation production process: a cross-region empirical study of China's high-tech innovations," Technovation, vol. 30, no. 5-6, pp. 348-358, 2010.

[20] W. Zhong, W. Yuan, S. X. Li, and Z. Huang, "The performance evaluation of regional R\&D investments in China: an application of DEA based on the first official China economic census data," Omega, vol. 39, no. 4, pp. 447-455, 2011.

[21] S. Wang, J. Fan, D. Zhao, and S. Wang, "Regional innovation environment and innovation efficiency: the Chinese case," Technology Analysis \& Strategic Management, vol. 28, no. 4, pp. 396-410, 2016.

[22] E. C. Wang and W. Huang, "Relative efficiency of R\&D activities: a cross-country study accounting for environmental factors in the DEA approach," Research Policy, vol. 36, no. 2, pp. 260-273, 2007.

[23] U. Khalid and Z. Liu, "Innovation index framework to measure the innovation capacity and efficiency of SAARC countries," European Journal of Social Sciences, vol. 46, no. 3, pp. 325-338, 2015.

[24] J. Ma and B. Bao, "Research on bullwhip effect in energyefficient air conditioning supply chain," Journal of Cleaner Production, vol. 143, pp. 854-865, 2017.

[25] D. E. Heckler, "High-technology employment: a NAICSbased update," Monthly Labor Review, vol. 128, no. 7, pp. 57-70, 2005.

[26] J. Ma, A. Hou, and Y. Tian, "Research on the complexity of green innovative enterprise in dynamic game model and governmental policy making," Chaos, Solitons \& Fractals: X, vol. 2, Article ID 100008, 2019.

[27] J. Ma and H. Ren, "Influence of government regulation on the stability of dual-channel recycling model based on customer expectation," Nonlinear Dynamics, vol. 94, no. 3, pp. 1775-1790, 2018.

[28] D. Aigner, C. A. K. Lovell, and P. Schmidt, "Formulation and estimation of stochastic frontier production function models," Journal of Econometrics, vol. 6, no. 1, pp. 21-37, 1977.

[29] S. Yin and L. Chen, "Technological innovation efficiency of Chinese pharmaceutical firms based on two-phase SFA study," Soft Science, vol. 30, no. 5, pp. 54-58, 2016.

[30] X. Bi, S. Zhai, and Q. He, "Does financial slack reduce enterprises' innovation efficiency?Discussing the governance effect of balance of ownership structure," R\&D Management, vol. 29, no. 2, pp. 82-92, 2017.

[31] A. Charnes, W. W. Cooper, and E. Rhodes, "Measuring the efficiency of decision making units," European Journal of Operational Research, vol. 2, no. 6, pp. 429-444, 1978.

[32] L. Liu and X. Zhan, "Analysis of financing efficiency of Chinese agricultural listed companies based on machine learning," Complexity, vol. 2019, Article ID 9190273, 2019.

[33] M. Yi, J. Peng, and Y. Yu, "Research on Evaluation and improvement strategies of technological innovation efficiency of China's high-tech industry," Macroeconomics, vol. 11, pp. 60-68, 2017.

[34] L.-B. Li, B.-L. Liu, W.-L. Liu, and Y.-H. Chiu, "Efficiency evaluation of the regional high-tech industry in China: a new framework based on meta-frontier dynamic DEA analysis," Socio-Economic Planning Sciences, vol. 60, pp. 24-33, 2017.

[35] G. H. Jefferson, H. Bai, X. Guan, and X. Yu, "R\&D performance in Chinese industry," Economics of Innovation and New Technology, vol. 15, no. 4-5, pp. 345-366, 2006.

[36] D. Zhu and X. Zhou, "Equity restriction, managerial ownership and enterprise," Nankai Business Review, vol. 19, no. 3, pp. 136-144, 2016.

[37] J. Hong, B. Feng, Y. Wu, and L. Wang, "Do government grants promote innovation efficiency in China's high-tech industries?" Technovation, vol. 57-58, pp. 4-13, 2016.

[38] B. Jiao, W. Huang, Z. Xie, and L. Lo, "Study on the relationship between high-tech industrial regional agglomeration and R\&D efficiency," Agro Food Industry Hi-Tech, vol. 27, no. 6, pp. 70-77, 2016.

[39] Z. Liu, X. Chen, J. Chu, and Q. Zhu, "Industrial development environment and innovation efficiency of high-tech industry: analysis based on the framework of innovation systems," Technology Analysis \& Strategic Management, vol. 30, no. 4, pp. 434-446, 2017.

[40] P. Anderson and N. C. Peterson, "A procedure for ranking efficient units in Data envelopment analysis," Management Science, vol. 39, pp. 1261-1264, 1993.

[41] K. Tone, "A slacks-based measure of efficiency in data envelopment analysis," European Journal of Operational Research, vol. 130, no. 3, pp. 498-509, 2001.

[42] K. Tone, "A slacks-based measure of super-efficiency in data envelopment analysis," European Journal of Operational Research, vol. 143, no. 1, pp. 32-41, 2002.

[43] M. Crosby, "Patents, innovation and growth," Economic Record, vol. 76, no. 234, pp. 255-262, 2000.

[44] C. Bérubé and P. Mohnen, "Are firms that receive R\&D subsidies more innovative?" Canadian Journal of Economics/ Revue Canadienne D'économique, vol. 42, no. 1, pp. 206-225, 2009. 
[45] F. Yu, Y. Guo, K. Le-Nguyen, S. J. Barnes, and W. Zhang, "The impact of government subsidies and enterprises' R\&D investment: a panel data study from renewable energy in China," Energy Policy, vol. 89, pp. 106-113, 2016.

[46] M. Hud and K. Hussinger, "The impact of R\&D subsidies during the crisis," Research Policy, vol. 44, no. 10, pp. 1844-1855, 2015.

[47] A. Shleifer and R. W. Vishny, "Large shareholders and corporate control," Journal of Political Economy, vol. 94, no. 3, pp. 461-488, 1986.

[48] V. Z. Chen, J. Li, D. M. Shapiro, and X. Zhang, "Ownership structure and innovation: an emerging market perspective," Asia Pacific Journal of Management, vol. 31, no. 1, pp. 1-24, 2014.

[49] C. Chen, C. Chien, M. Lin, and J. Wang, "Using DEA to evaluate R\&D performance of the computers and peripherals firms in Taiwan," International Journal of Business, vol. 9, no. 4, pp. 347-359, 2004.

[50] J. Wang and K. Tsai, "Productivity Growth and R\&D Expenditure in Taiwan's Manufacturing Firms," NBER Working Papers: 9724, National Bureau of Economic Research, Cambridge, MA, USA, 2004.

[51] D. Aboal, P. Garda, B. Lanzilotta, and M. Perera, "Innovation, firm size, technology intensity, and employment generation: evidence from the Uruguayan manufacturing sector," Emerging Markets Finance and Trade, vol. 51, no. 1, pp. 3-26, 2015.

[52] D. Shefer and A. Frenkel, "R\&D, firm size and innovation: an empirical analysis," Technovation, vol. 25, no. 1, pp. 25-32, 2005.

[53] X. Luo, "Research on R\&D subsidies and technological innovation efficiency of high-tech enterprises_- based on the threshold effect of firm size," Review of Investment Studies, vol. 38, no. 10, pp. 52-66, 2019.

[54] P. Aghion, J. Cai, M. Dewatripont, L. Du, A. Harrison, and P. Legros, "Industrial policy and competition," American Economic Journal: Macroeconomics, vol. 7, no. 4, pp. 1-32, 2015.

[55] S. K. Majumdar, "The impact of size and age on firm-level performance: some evidence from India," Review of Industrial Organization, vol. 12, no. 2, pp. 231-241, 1997.

[56] N. Balasubramanian and J. Lee, "Firm age and innovation," Industrial and Corporate Change, vol. 17, no. 5, pp. 1019-1047, 2008.

[57] S. R. Herriott, D. Levinthal, and J. G. March, "Learning from experience in organizations," The American Economic Review, vol. 75, no. 2, pp. 298-302, 1985.

[58] E. Sivadas and F. R. Dwyer, "An examination of organizational factors influencing new product success in internal and alliance-based processes," Journal of Marketing, vol. 64, no. 1, pp. 31-49, 2000. 